\title{
The potential for a great earthquake along the southernmost Ryukyu subduction zone
}

\author{
Ya-Ju Hsu, ${ }^{1}$ Masataka Ando, ${ }^{1}$ Shui-Beih Yu, ${ }^{1}$ and Mark Simons ${ }^{2}$ \\ Received 16 June 2012; accepted 18 June 2012; published 26 July 2012.
}

[1] Interseismic GPS data along the Hualien-Suao coast (NE Taiwan) shows a pattern of strain accumulation that is consistent with a potential future large shallow earthquake along the southernmost Ryukyu subduction zone. The measured shortening rate parallel to the Ryukyu Trench is $80 \mathrm{~mm} / \mathrm{yr}$, about twice of the shortening rate perpendicular to the Ryukyu Trench. We invert for slip-deficit rates and the geometric configuration of the plate interface. Our preferred fault model dips $10^{\circ}$ northward and extends about $70 \mathrm{~km}$ from the Ryukyu Trench to a depth of $13 \mathrm{~km}$. The slipdeficit rate exhibits a left-lateral motion of $78 \mathrm{~mm} / \mathrm{yr}$ and a normal motion of $36 \mathrm{~mm} / \mathrm{yr}$ on a $290^{\circ}$-trending fault. The slip rate budget of the southernmost Ryukyu subduction zone is close to the plate convergence rate, suggesting the plate interface is fully locked. Assessments of seismic hazard in this region need to consider the potential threat from $\mathrm{M}_{\mathrm{w}}$ 7.5 8.7 tsunami earthquakes generated by shallow ruptures. Citation: Hsu, Y.-J., M. Ando, S.-B. Yu, and M. Simons (2012), The potential for a great earthquake along the southernmost Ryukyu subduction zone, Geophys. Res. Lett., 39, L14302, doi:10.1029/ 2012GL052764.

\section{Introduction}

[2] The Ryukyu Trench extends $2200 \mathrm{~km}$ southwestward from Kyushu, Japan to Taiwan. We focus on the southernmost Ryukyu subduction zone located between eastern Taiwan and Yonaguni Island $\left(123^{\circ} \mathrm{E}\right.$, Figure 1). Along the Ryukyu Trench, the Philippine Sea Plate (PSP) subducts beneath the Eurasian Plate (EU) at a rate of $80-85 \mathrm{~mm} / \mathrm{yr}$ in a $300^{\circ}-310^{\circ}$ direction (Figure 1) [Seno et al., 1993; Yu et al., 1997; Sella et al., 2002; Hsu et al., 2009]. Major structures from the Ryukyu Trench to the north offshore eastern Taiwan include the accretionary prism, two fore-arc basins (Hoping Basin and Nanao Basin), the Ryukyu Arc, and the Okinawa Trough, an actively rifting back-arc basin (Figures 2 (top) and 3). Geological and geophysical data reveal that the Okinawa Trough is undergoing active opening [Sibuet et al., 1987] at a spreading rate of $\sim 50 \mathrm{~mm} / \mathrm{yr}$ in the direction of $175^{\circ}$ at the southern Ryukyu Islands $\left(\sim 123.6^{\circ} \mathrm{E}\right)$ [Nishimura et al., 2004]. Given the convergence rate of about 80 $85 \mathrm{~mm} / \mathrm{yr}$ between the PSP and the EU, the shortening rate between the southern part of the Ryukyu Arc and the PSP is

\footnotetext{
${ }^{1}$ Institute of Earth Sciences, Academia Sinica, Nankang, Taipei, Taiwan.

${ }^{2}$ Seismological Laboratory, California Institute of Technology, Pasadena, California, USA.

Corresponding author: Y.-J. Hsu, Institute of Earth Sciences, Academia Sinica, 128 Academia Rd., Sec. 2, Nankang, Taipei 115, Taiwan. (yaru@earth.sinica.edu.tw)

(C)2012. American Geophysical Union. All Rights Reserved. 0094-8276/12/2012GL052764
}

up to $125 \mathrm{~mm} / \mathrm{yr}$. Bathymetry on the PSP reveals a distinct linear structure, the Gagua Ridge (Figure 1), which trends $\mathrm{N}-\mathrm{S}$, extending over $300 \mathrm{~km}$ in length and $20-30 \mathrm{~km}$ in width, and rises 2 to $4 \mathrm{~km}$ above the adjacent seafloor [Deschamps et al., 1998]. The ridge subducted beneath the Ryukyu Trench north of $23^{\circ} \mathrm{N}$ latitude.

[3] Subduction zones characterized with active back-arc rifting are traditionally considered to be decoupled, or aseismic [Uyeda and Kanamori, 1979; Scholz and Campos, 1995]. However, two recent $M_{w} 7.8$ thrust earthquakes with a combined moment equivalent to a $\mathrm{M}_{\mathrm{w}} 8$ were triggered after the $2009 \mathrm{M}_{\mathrm{w}} 8.1$ Samoa-Tonga earthquake [Lay et al., 2010]. The epicenters are located in the Tonga region where the maximum back-arc spreading rate is $160 \mathrm{~mm} / \mathrm{yr}$ [Bevis et al., 1995]. Historically, the 24 April 1771 Yaeyama, Japan earthquake $\left(\mathrm{M}_{\mathrm{w}} \sim 8\right)$ broke the shallow portion of the southern Ryukyu subduction zone (124 125.4 ${ }^{\circ}$ E, Figure 1) and generated a large tsunami with a maximum runup of $30 \mathrm{~m}$ on the Ishigaki Island [Nakamura, 2009a]. These events near an active back-arc basin motivate us to reassess the extent of plate coupling on the plate interface and the associated seismic hazard along the southern Ryukyu Trench.

[4] Based on historic earthquakes in Taiwan, at least ten events with magnitudes larger than 7 have occurred offshore northeast Taiwan over the past hundred years, the largest of which was a $\mathrm{M}_{\mathrm{w}} 7.7$ on June 5th, 1920 [Theunissen et al., 2010] and a more recent $M_{w} 7.1$ event on March 31, 2002 (Figure 2, top). While hard to determine, the 1920 event may have occurred on the Ryukyu megathrust. Seismicity between 1990 and 2011 at focal depths of 10 30 km appears to be clustered at the southern flank of the Ryukyu Arc (Figure 2); while seismicity is absent between the Ryukyu Trench and the accretionary prism. These features suggest two extreme hypotheses that the plate interface at shallow depths is aseismic [Hyndman et al., 1995; Hsu et al., 2006] or alternatively completed locked. If a shallow subduction zone earthquake occurs, it may produce a large tsunami [Kanamori, 1972; Satake and Tanioka, 1999; Polet and Kanamori, 2000]. Results from recent studies of shallow megathrust earthquakes near trench axes show that the plate interface at shallow depths can generate large earthquakes and tsunamis [Abercrombie et al., 2001; Kanamori et al., 2010; Lay et al., 2011; Simons et al., 2011].

[5] Vertical velocities inferred from continuous GPS (CGPS) observations show that the northern part of the Hualien-Taitung coast in eastern Taiwan is subsiding at a rate of about $10 \mathrm{~mm} / \mathrm{yr}$, while the southern portion is uplifting with a rate of $10-20 \mathrm{~mm} / \mathrm{yr}$ (Figure 3a). The long-term uplift rates inferred from marine/river terraces and mass mortality of intertidal organisms show a northward decrease in uplift rates. The long-term uplift rate on the east coast is 3-15 mm/yr [Hsieh et al., 2004; Yamaguchi and Ota, 2004; 


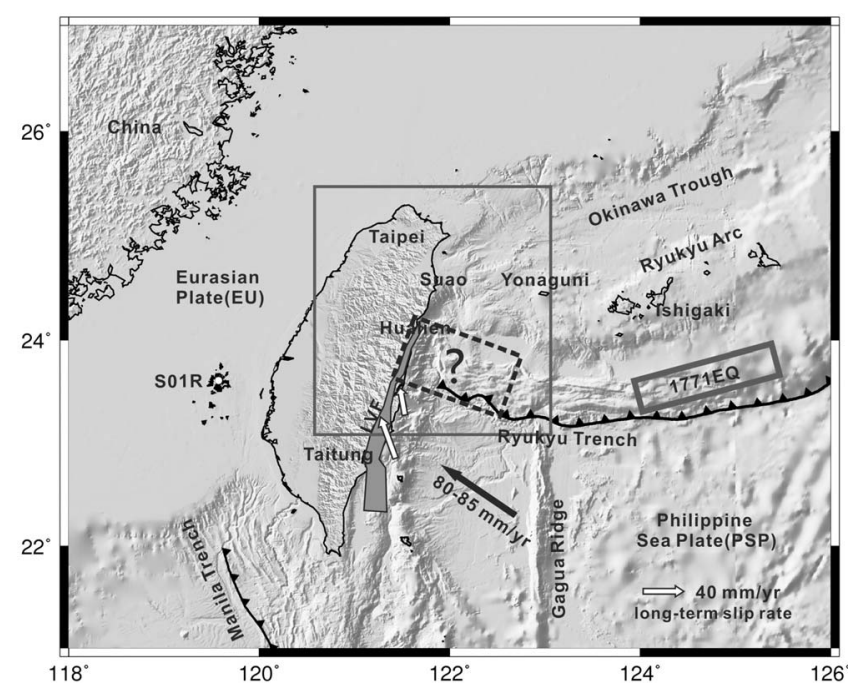

Figure 1. Tectonic setting in the Taiwan plate boundary zone. The grey box indicates the study area. The black vector shows the plate convergence between the Eurasian (EU) and the Philippine Sea Plate (PSP). The CGPS site, S01R, is the reference station for GPS velocities in Figure 3a. The rectangle with dash lines and question mark indicates the potential rupture source inferred in this study. The shaded region shows the Longitudinal Valley Fault (LVF) projected on the surface with long-term slip rates shown in white arrows [Ching et al., 2011]. The rectangle box near $125^{\circ} \mathrm{E}$ is the rupture source of the 1771 Yaeyama tsunami earthquake [Nakamura, 2009a].

Hsieh and Rau, 2009]. Magnitudes of coseismic motions inferred from vertical spacing between marine terraces are typically $3-5 \mathrm{~m}$, significantly larger than the vertical displacements generated along the Longitudinal Valley Fault (LVF, Figure 1) [Yamaguchi and Ota, 2004]. The LVF is located at the plate suture zone between the EU and the PSP. The fault strikes NNE with high angle dip to the east extends about $140 \mathrm{~km}$ from Taitung to Hualien and exhibits both leftlateral and reverse motions (Figure 1). The shortening rate across the LVF is about $30 \mathrm{~mm} / \mathrm{yr}$ and the fault motion progressively changes from predominately oblique motion (reverse/left-lateral slip) on the southern section to left-lateral slip north of Fengping [Yu et al., 1997; Yu and Kuo, 2001]. Observed large coseismic uplifts as inferred from the marine terraces along the eastern coast of Taiwan may be a direct result of megathrust earthquakes along the Ryukyu Trench.

[6] In this study, we use CGPS data spanning the time period from 2005 to 2010 to infer the fault geometry and the slip-deficit rate on the southernmost Ryukyu subduction zone. Since available data is restricted to a narrow zone perpendicular to the southern Ryukyu Trench, a detailed plate coupling model is not possible, thus we aim to only examine first-order features using a simple elastic dislocation model.

\section{GPS Data}

[7] To constrain our model, we use 19 CGPS sites (for more details on the GPS processing, please see Text S1 in the auxiliary material) located along the Hualien-Suao coast between latitude $23.2^{\circ} \mathrm{N}$ and $24.6^{\circ} \mathrm{N}$ (shown in Figure 3a). ${ }^{1}$ Horizontal and vertical velocities with respect to site S01R, located at Penghu (Figure 1), are shown in Figure 3a. North of Suao, CGPS sites in the Ilan Plain are strongly affected by rifting of the Okinawa Trough [Liu, 1995]. The stress regime is extensional in the Ilan plain and different from the compressional stress regime from Hualien to Suao [Hsu et al., 2009] (Figure S1 in Text S1). We decompose GPS velocities into trench-normal $\left(20^{\circ}\right)$ and trench-parallel $\left(290^{\circ}\right)$ components and refer velocities to the SUAO site (Figure $3 b$ ).
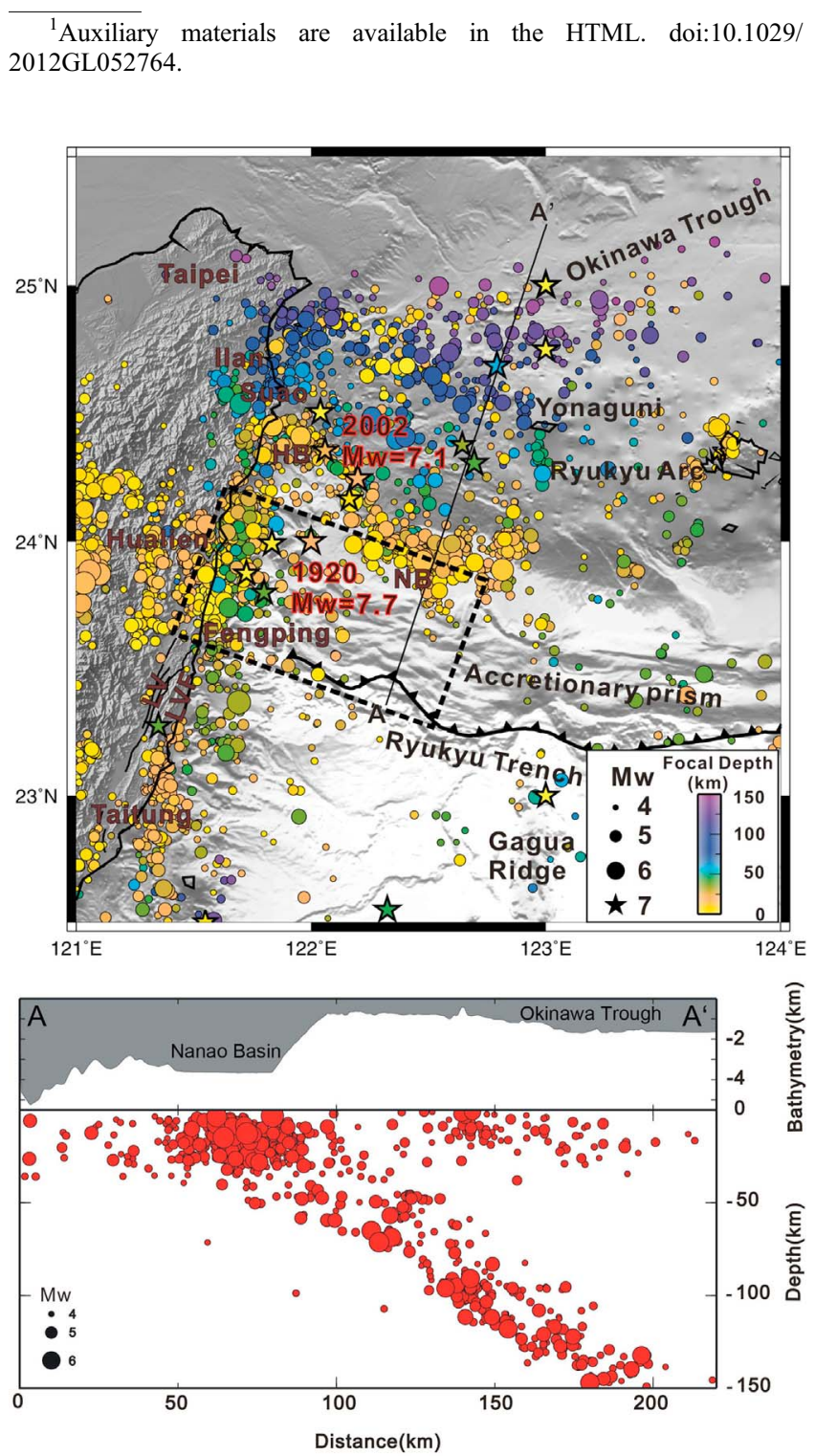

Figure 2. (top) Seismicity with $\mathrm{M}_{\mathrm{L}}>4$ between 1990 and 2011 from the Central Weather Bureau of Taiwan. Color circle indicates focal depths and its size is proportional to the magnitude. The stars denote the historic events with $M_{\mathrm{w}}>7$ between 1900 and 2007 from Theunissen et al. [2010]. The rectangle denotes the potential rupture fault along the Ryukyu Trench. LV: Longitudinal Valley, LVF: Longitudinal Valley Fault, HB: Hoping Basin, NB: Nanao Basin. (bottom) Seismicity and bathymetry along the crosssection $\mathrm{A}-\mathrm{A}^{\prime}$ in the top plot. Circle size is proportional to the magnitude. 

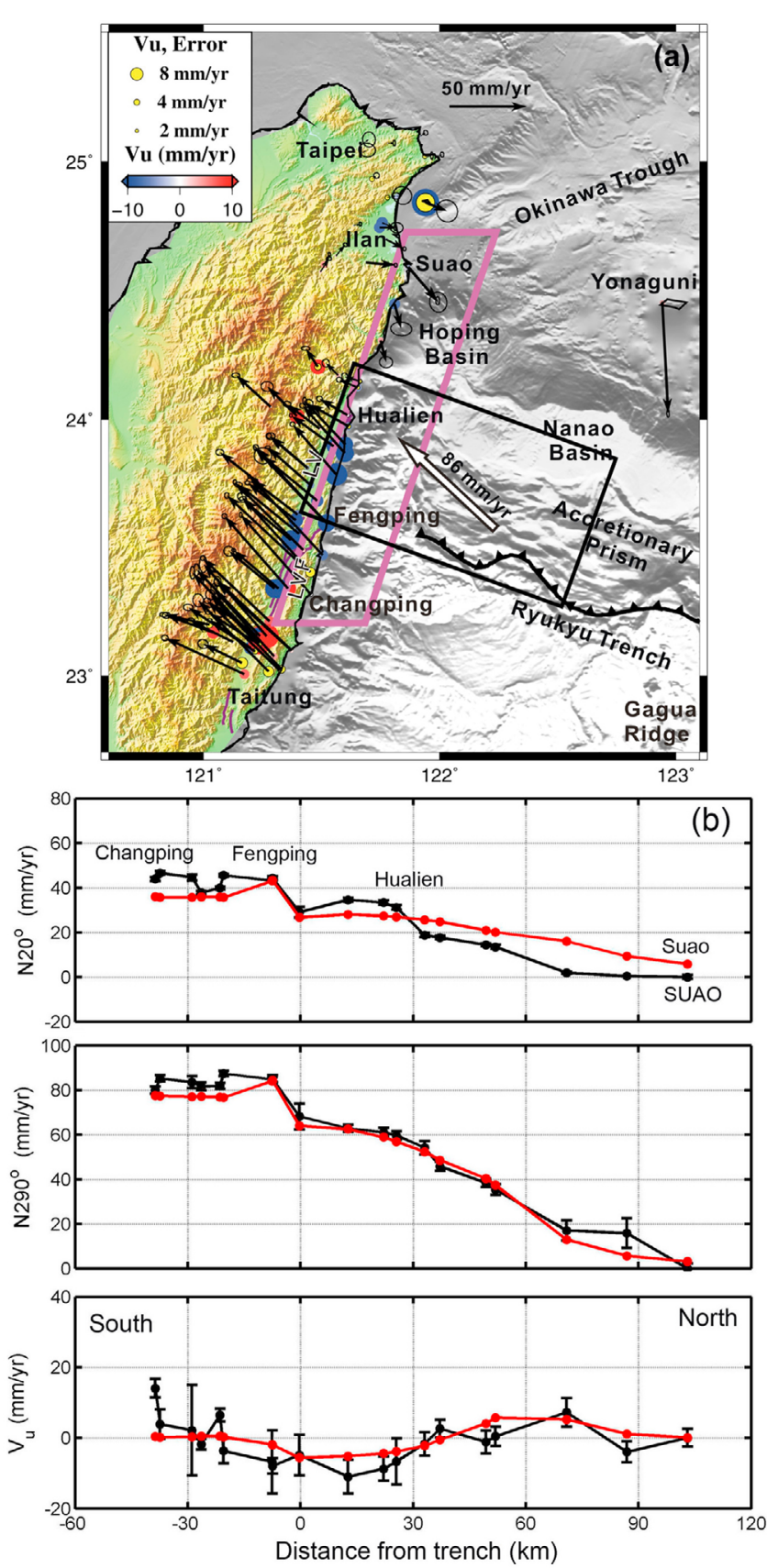

Figure 3. (a) The GPS velocity field with respect to S01R between 2005 and 2010. Horizontal velocities are shown in black vectors with $95 \%$ confidence ellipses from GLOBK. Vertical velocities are shown by circles with uplift and subsidence indicated by red and blue colors, respectively. Magenta box indicates the region for selected GPS sites in this study. The black rectangle denotes the potential rupture fault along the Ryukyu Trench with a white arrow showing the slip-deficit rate. LV: Longitudinal Valley, LVF: Longitudinal Valley Fault. (b) Black and red lines indicate observed and predicted trench-normal $\left(20^{\circ}\right)$, trench-parallel $\left(290^{\circ}\right)$, and vertical velocities, respectively. The CGPS site, SUAO, is the reference site for these profiles.
Shortening rates of the normal and parallel components from Fengping to Suao are about 40 and $80 \mathrm{~mm} / \mathrm{yr}$, respectively. The magnitude of the trench-parallel component is about twice that of the trench normal component. The accumulated strain in this region (Figure 3b) is likely consumed on the adjacent fault systems, the LVF in eastern Taiwan or the southernmost Ryukyu subduction zone. A preliminary model simultaneously explores the impact of strain accumulation on the LVF and the Ryukyu megathrust suggesting that the accumulated strain to the north of latitude $23.5^{\circ} \mathrm{N}$ is mostly due to fault locking on the Ryukyu megathrust (see details in the auxiliary material). In addition, the largest strain rate occurs north of Hualien (Figure 3b), well beyond the northern termination of the LVF at Hualien. No onland active faults between Hualien and Suao can explain the strain accumulation pattern shown in Figure 3. Thus, we infer that the accumulated strain is predominately associated with coupling on the Ryukyu subduction zone megathrust.

\section{Dislocation Modeling}

[8] Here we test the hypothesis that the accumulated strain on the east coast of Taiwan can be fully accounted for by fault coupling along the shallow portion of the Ryukyu subduction megathrust. We use a backslip model to invert for slip-deficit rates on the fault using both GPS horizontal and vertical components. In the context of this model, the effect of interseismic strain accumulation can be represented as the sum of the long-term block motion across the plate boundary fault and the slip-deficit (backslip) on the locked fault zone [Savage, 1983]. For a given fault geometry, the slip-deficit rate can be inferred from the differences between the observed interseismic GPS velocities and the long-term block motion across the Ryukyu Trench. The long-term block motion, i.e. plate motion, between the EU and the PSP is well constrained from previous studies [Seno et al., 1993; Yu et al., 1997; Sella et al., 2002; Hsu et al., 2009] with a convergence rate of $80-85 \mathrm{~mm} / \mathrm{yr}$ in a direction of $300^{\circ} \sim 310^{\circ}$.

[9] Since our dataset is restricted to a narrow zone perpendicular to the Ryukyu Trench (Figure 3a), we do not attempt to solve for slip variation along the strike of the Ryukyu Trench. We use an elastic dislocation model [Okada, 1985] with a uniform fault slip rate. The western edge of the fault model, i.e., the western termination of the Ryukyu Trench, is bounded in the Longitudinal Valley on the basis of seismicity and 3-D velocity structures from $\mathrm{Wu}$ et al. [2009] and the fault extends to infinity on the eastern side. The fault plane is oriented in $290^{\circ}$, roughly following the trend of the Ryukyu Trench (Figures 2 and 3). We use a grid search to find the optimal fault parameters and slip-deficit rates (see details in the auxiliary material). The fit to the data is quantified from the mean of the normalized square residuals, $\chi_{r}^{2}$. A $\chi_{r}^{2}$ value of 1 indicates that on average the model fits the data within uncertainties.

\section{Results and Discussion}

[10] Our preferred fault model trends $290^{\circ}$ from north, dips $10^{\circ}$ northward, and extends from the Ryukyu Trench to a depth of $13 \mathrm{~km}$ corresponding to a downdip width of $69 \mathrm{~km}$. We find a slip-deficit rate of $86 \mathrm{~mm} / \mathrm{yr}$ with a left-lateral motion of $78 \mathrm{~mm} / \mathrm{yr}$ and a normal motion of $36 \mathrm{~mm} / \mathrm{yr}$. (Figure 3a). We obtain an optimal long-term block motion of 
$87 \mathrm{~mm} / \mathrm{yr}$ in the direction of $315^{\circ}$, consistent with estimates of EU-PSP relative plate convergence rates of $80-85 \mathrm{~mm} / \mathrm{yr}$. The estimated slip-deficit rate of $86 \mathrm{~mm} / \mathrm{yr}$ is similar to the estimated block motion of $87 \mathrm{~mm} / \mathrm{yr}$, implying that the shallow portion of the southern Ryukyu subduction zone is fully locked. Fits to trench-normal, trench-parallel and vertical components are shown in Figure 3b.

[11] Our model predictions generally fit the surface GPS velocities with average residuals of $6.3,3.9$, and $4.1 \mathrm{~mm} / \mathrm{yr}$ in the $20^{\circ}, 290^{\circ}$, and vertical components, respectively. The optimal model has a value of $\chi_{r}^{2}$ of 12.6 , is significantly larger than 1. The large misfits may suggest that the GPS observation errors are under-estimated or a simple uniform slip model is not able to produce a small misfit. Nevertheless, the model predictions are able to fit the first-order signals in observed GPS velocities and explain the observed subsidence along the Hualien coast (Figure 3b). To explore the impact of a non-uniform slip-deficit rate perpendicular to the Ryukyu Trench, we also considered a variety of forward models with locking increasing/decreasing as a function of depth. All tested models require that the plate interface at shallow depths to be fully coupled (method and results are given in the auxiliary material; see Figure S3).

[12] We infer that the shallow portion of plate interface is locked and the future rupture at the southernmost Ryukyu subduction zone will likely be oblique with predominately right-lateral motion close to the east coast of Taiwan and reverse motion near Yonaguni Island (see details in the auxiliary material (Figure S4)). The preferred fault model intersects eastern Taiwan at latitude of $23.6^{\circ} \mathrm{N}$, consistent with the western termination of the Ryukyu Trench at latitude $23.7^{\circ} \mathrm{N}$ [ $W u$ et al. 2009]. Limited by insufficient GPS data coverage along the strike of the Ryukyu Trench, the spatial extent of the locked fault patch offshore eastern Taiwan is not well resolved (see details in the auxiliary material (Figure S5)). We examine the seismicity and bathymetry to provide some clues for the spatial extent of plausible future rupture. Seismicity is clustered between the Hoping Basin and the Nanao Basin where the Gagua Ridge subducts northwards (Figure 2a). The cluster of seismicity is likely to follow the boundary between the locked fault zone and the creeping zone which is often seen on continental thrust faults [Cattin and Avouac, 2000; Dominguez et al., 2003]. The Gagua Ridge may act as a barrier to prohibit continuous rupture to the east. Thus, we suggest future plausible large earthquakes may extend from the east coast of Taiwan to the Gagua Ridge, with possible rupture lengths of about $120 \mathrm{~km}$ and widths of about $70 \mathrm{~km}$, as constrained from our inversion results and historical seismicity. Of course, we cannot rule out the possibility that a future event could extend on both sides of the Gagua Ridge. Using empirical relationships, for a potential rupture area of $8400 \mathrm{~km}^{2}(120 \mathrm{~km} \times 70 \mathrm{~km})$, we would expect an earthquake in the magnitude range of 7.5 8 [Wells and Coppersmith, 1994]. Alternatively, if we assume the rigidity of $30 \mathrm{GPa}$, a slip-deficit rate of $86 \mathrm{~mm} / \mathrm{yr}$, and a recurrence interval of 500 years (see details in the auxiliary material), the potential earthquake magnitude is about 8.7, if accumulated strain is fully released in this type of event. However, a future earthquake could potentially be much larger given the high stress drop observed for the recent Tohoku-Oki earthquake [Simons et al., 2011] or substantially lower if the accumulated strain across the Ryukyu
Trench is either partially released aseismically after a large earthquake [e.g., Hsu et al., 2006] or even accounted by slip on other faults. For instance, Lallemand et al. [1997] reported a WNW-trending tear fault located on the southern side of Nanao Basin. This fault may account for a portion of the accumulated right-lateral motions during future earthquakes. Additionally, we cannot exclude the possibly of rupture along splay faults in the accretionary prism [Font and Lallemand, 2009; Theunissen et al., 2010]. Limited by insufficient data close to trench axis, seafloor geodetic surveys close to the Ryukyu Trench are crucial to distinguish the detailed fault coupling patterns [Ando et al., 2009].

[13] Kao [1998] examined the seismogenic conditions in the southernmost Ryukyu Arc-Taiwan region and concluded the potential threat from frequent occurrences of $\mathrm{M}_{\mathrm{w}}>7$ events cannot be ignored while the occurrences of $\mathrm{M}_{\mathrm{W}}>8$ subduction earthquakes seems to be unlikely [Kao, 1998]. On the other hand, aseismic slip after the $2002 \mathrm{M}_{\mathrm{w}} 7.1$ Hualien earthquake has been observed to the south of Yonaguni Island at a depth of $30 \mathrm{~km}$ [Nakamura, 2009b]. Heki and Kataoka [2008] found about 20 slow-slip events occurred during period 1997 to 2007 on the southern Ryukyu Islands. They infer a slip zone between 20 and $40 \mathrm{~km}$ depths. On average, these slow-slip have equivalent seismic moments of $\mathrm{M}_{\mathrm{w}} 6.6$ [Heki and Kataoka, 2008]. Despite these aseismic slip events, no shallow aseismic slip (depth $<15 \mathrm{~km}$ ) has been reported in this area - although detection of any events is hampered by lack of observations. Ando et al. [2012] found very low frequency events with low-angle thrust faulting occur mostly in the accretionary prism of southern Ryukyu subduction zone, which are similar to those earthquakes found in Honshu and Hokkaido, Japan. The locations and mechanisms of these events seem to suggest the upper interface of Ryukyu Trench is locked [Ando et al., 2012], consistent with our modeling results. The maximum likely magnitude of a future event is probably about 8 at the southernmost Ryukyu subduction zone. Given the results presented here and the evidence from the 1771 Yaeyama, Japan earthquake, the potential threat from tsunamis should not be ignored. [Nakamura, 2009a].

\section{Conclusions}

[14] The inversion of interseismic GPS data along the Hualien-Taitung coast suggests that the plate interface is fully locked from the Ryukyu Trench to a depth of $13 \mathrm{~km}$ at the southernmost Ryukyu subduction zone. The potential rupture zone is likely to extend from the east coast of Taiwan to the Gagua Ridge with plausible magnitudes as large as 7.5 to 8.7 . We are not able to exclude the possibility of even larger events. Coseismic slip will likely be oblique with predominately right-lateral motion. To better evaluate the rupture scenarios, seafloor geodetic observations on both sides of the Ryukyu Trench are required.

[15] Acknowledgments. The authors thank the Editor, Andrew Newman, as well as Emma Hill and an anonymous reviewer for their constructive suggestions. The generous provision of continuous GPS data at the Ryukyu Islands from GEONET (GPS Earth Observation Network) established by the Geographical Survey Institute (GSI), Japan is appreciated. We thank the Central Weather Bureau and Ministry of the Interior, Taiwan and IGS community. GMT was used to create several figures [Wessel and Smith, 1998]. This is the contribution of the National Science Council of the Republic of China grant NSC 98-2119-M-001-033-MY3; the Institute 
of Earth Sciences, Academia Sinica, IESAS1716; Caltech Seismological Laboratory, Seismo 10077, and Tectonics Observatory, TO\# 204.

\section{References}

Abercrombie, R. E., M. Antolik, K. Felzer, and G. Ekstrom (2001) The 1994 Java tsunami earthquake: Slip over a subducting seamount, J. Geophys. Res., 106, 6595-6607, doi:10.1029/2000JB900403.

Ando, M., M. Nakamura, T. Matsumoto, M. Furukawa, K. Tadokoro, and M. Furumoto (2009), Is the Ryukyu subduction zone in Japan coupled or decoupled? The necessity of seafloor crustal deformation observation, Earth Planets Space, 61, 1031-1039.

Ando, M., Y. T.-L. Tu, Y. Kumagai, Y. Yamanaka, and C.-H. Lin (2012), Very low frequency earthquakes along the Ryukyu subduction zone, Geophys. Res. Lett., 39, L04303, doi:10.1029/2011GL050559.

Bevis, M., et al. (1995), Geodetic observations of very rapid convergence and back-arc extension at the Tonga arc, Nature, 374, 249-251, doi:10.1038/374249a0

Cattin, R., and J. P. Avouac (2000), Modeling mountain building and the seismic cycle in the Himalaya of Nepal, J. Geophys. Res., 105, 13,389-13,407, doi:10.1029/2000JB900032.

Ching, K. E., R. J. Rau, K. M. Johnson, J. C. Lee, and J. C. Hu (2011) Present-day kinematics of active mountain building in Taiwan from GPS observations during 1995-2005, J. Geophys. Res., 116, B09405, doi:10.1029/2010JB008058.

Deschamps, A. E., S. E. Lallemand, and J. Y. Collot (1998), A detailed study of the Gagua Ridge: A fracture zone uplifted during a plate reorganisation in the Mid-Eocene, Mar. Geophys. Res., 20, 403-423, doi:10.1023/A:1004650323183

Dominguez, S., J. P. Avouac, and R. Michel (2003), Horizontal coseismic deformation of the 1999 Chi-Chi earthquake measured from SPOT satellite images: Implications for the seismic cycle along the western foothills of central Taiwan, J. Geophys. Res., 108(B2), 2083, doi:10.1029/ 2001JB000951.

Font, Y., and S. Lallemand (2009), Subducting oceanic high causes compressional faulting in southernmost Ryukyu forearc as revealed by hypocentral determinations of earthquakes and reflection/refraction seismic data, Tectonophysics, 466, 255-267, doi:10.1016/j.tecto.2007.11.018.

Heki, K., and T. Kataoka (2008), On the biannually repeating slow-slip events at the Ryukyu Trench, southwestern Japan, J. Geophys. Res., 113, B11402, doi:10.1029/2008JB005739.

Hsieh, M.-L., and R.-J. Rau (2009), Late Holocene coseismic uplift on the Hua-tung coast, eastern Taiwan: Evidence from mass mortality of intertidal organisms, Tectonophysics, 474, 595-609, doi:10.1016/j.tecto. 2009.04.031.

Hsieh, M. L., P. M. Liew, and M. Y. Hsu (2004), Holocene tectonic uplift on the Hua-tung coast, eastern Taiwan, Quat. Int., 115-116, 47-70, doi:10.1016/S1040-6182(03)00096-X.

Hsu, Y. J., M. Simons, J. P. Avouac, J. Galetzka, K. Sieh, M. Chlieh, D. Natawidjaja, L. Prawirodirdjo, and Y. Bock (2006), Frictional afterslip following the 2005 Nias-Simeulue earthquake, Sumatra, Science, 312, 1921-1926, doi:10.1126/science.1126960.

Hsu, Y. J., S. B. Yu, M. Simons, L. C. Kuo, and H. Y. Chen (2009), Interseismic crustal deformation in the Taiwan plate boundary zone revealed by GPS observations, seismicity, and earthquake focal mechanisms, Tectonophysics, 479, 4-18, doi:10.1016/j.tecto.2008.11.016.

Hyndman, R. D., K. Wang, and M. Yamano (1995), Thermal constraints on the seismogenic portion of the southwestern Japan subduction thrust, J. Geophys. Res., 100, 15,373-15,392, doi:10.1029/95JB00153.

Kanamori, H. (1972), Mechanism of tsunami earthquakes, Phys. Earth Planet. Inter., 6, 346-359, doi:10.1016/0031-9201(72)90058-1.

Kanamori, H., L. Rivera, and W. H. K. Lee (2010), Historical seismograms for unravelling a mysterious earthquake: The 1907 Sumatra earthquake, Geophys. J. Int., 183, 358-374, doi:10.1111/j.1365-246X.2010.04731.x.

Kao, H. (1998), Can great earthquakes occur in the southernmost Ryukyu arc-Taiwan region?, Terr. Amos. Oceanic Sci., 9, 487-508.

Lallemand, S. E., C. S. Liu, and Y. Font (1997), A tear fault boundary between the Taiwan orogen and the Ryukyu subduction zone, Tectonophysics, 274, 171-190, doi:10.1016/S0040-1951(96)00303-4.
Lay, T., C. J. Ammon, H. Kanamori, L. Rivera, K. D. Koper, and A. R. Hutko (2010), The 2009 Samoa-Tonga great earthquake triggered doublet, Nature, 466, 964-968, doi:10.1038/nature09214.

Lay, T., C. J. Ammon, H. Kanamori, Y. Yamazaki, K. F. Cheung, and A. R. Hutko (2011), The 25 October 2010 Mentawai tsunami earthquake $\left(\mathrm{M}_{\mathrm{w}} 7.8\right)$ and the tsunami hazard presented by shallow megathrust ruptures, Geophys. Res. Lett., 38, L06302, doi:10.1029/2010GL046552.

Liu, C. C. (1995), The Ilan plain and the southwestward extending Okinawa Trough, J. Geol. Soc. China, 38, 183-193.

Nakamura, M. (2009a), Fault model of the 1771 Yaeyama earthquake along the Ryukyu Trench estimated from the devastating tsunami, Geophys. Res. Lett., 36, L19307, doi:10.1029/2009GL039730.

Nakamura, M. (2009b), Aseismic crustal movement in southern Ryukyu Trench, southwest Japan, Geophys. Res. Lett., 36, L20312, doi:10.1029/ 2009GL040357.

Nishimura, S., M. Hashimoto, and M. Ando (2004), A rigid block rotation model for the GPS derived velocity field along the Ryukyu arc, Phys. Earth Planet. Inter., 142, 185-203, doi:10.1016/j.pepi.2003.12.014.

Okada, Y. (1985), Surface deformation due to shear and tensile faults in a half-space, Bull. Seismol. Soc. Am., 75, 1135-1154.

Polet, J., and H. Kanamori (2000), Shallow subduction zone earthquakes and their tsunamigenic potential, Geophys. J. Int., 142, 684-702, doi:10.1046/j.1365-246x.2000.00205.x

Satake, K., and Y. Tanioka (1999), Sources of tsunami and tsunamigenic earthquakes in subduction zones, Pure Appl. Geophys., 154, 467-483, doi: $10.1007 / \mathrm{s} 000240050240$.

Savage, J. C. (1983), A dislocation model of strain accumulation and release at a subduction zone, J. Geophys. Res., 88, 4984-4996, doi:10.1029/JB088iB06p04984.

Scholz, C. H., and J. Campos (1995), On the mechanism of seismic decoupling and back-arc spreading at subduction zones, J. Geophys. Res., 100, 22,103-22,115, doi:10.1029/95JB01869.

Sella, G. F., T. H. Dixon, and A. L. Mao (2002), REVEL: A model for Recent plate velocities from space geodesy, J. Geophys. Res., 107(B4), 2081, doi:10.1029/2000JB000033.

Seno, T., S. Stein, and A. E. Gripp (1993), A model for the motion of the Philippine Sea plate consistent with Nuvel-1 and geological data J. Geophys. Res., 98, 17,941-17,948, doi:10.1029/93JB00782.

Sibuet, J. C., et al. (1987), Back arc extension in the Okinawa trough, J. Geophys. Res., 92, 14,041-14,063, doi:10.1029/JB092iB13p14041.

Simons, M., et al. (2011), The 2011 magnitude 9.0 Tohoku-Oki earthquake: Mosaicking the megathrust from seconds to centuries, Science, 332, 1421-1425, doi:10.1126/science. 1206731 .

Theunissen, T., Y. Font, S. Lallemand, and W.-T. Liang (2010), The largest instrumentally recorded earthquake in Taiwan: Revised location and magnitude, and tectonic significance of the 1920 event, Geophys. J. Int., 183, 1119-1133, doi:10.1111/j.1365-246X.2010.04813.x.

Uyeda, S., and H. Kanamori (1979), Back-arc opening and the mode of subduction, J. Geophys. Res., 84, 1049-1061, doi:10.1029/JB084iB03p01049.

Wells, D. L., and K. J. Coppersmith (1994), New empirical relationships among magnitude, rupture length, rupture width, rupture area, and surface displacement, Bull. Seismol. Soc. Am., 84, 974-1002.

Wessel, P., and W. H. F. Smith (1998), New, improved version of Generic Mapping Tools released, Eos Trans. $A G U$, 79(47), 579, doi:10.1029/ 98EO00426.

Wu, F. T., W. T. Liang, J. C. Lee, H. Benz, and A. Villasenor (2009), A model for the termination of the Ryukyu subduction zone against Taiwan: A junction of collision, subduction/separation, and subduction boundaries, J. Geophys. Res., 114, B07404, doi:10.1029/2008JB005950.

Yamaguchi, M., and Y. Ota (2004), Tectonic interpretations of Holocene marine terraces, east coast of Coastal Range, Taiwan, Quat. Int., 115-116, 71-81, doi:10.1016/S1040-6182(03)00097-1.

Yu, S. B., and L. C. Kuo (2001), Present-day crustal motion along the Longitudinal Valley Fault, eastern Taiwan, Tectonophysics, 333, 199-217, doi:10.1016/S0040-1951(00)00275-4.

Yu, S. B., H. Y. Chen, and L. C. Kuo (1997), Velocity field of GPS stations in the Taiwan area, Tectonophysics, 274, 41-59, doi:10.1016/S00401951(96)00297-1. 